\title{
Public Law Declarators, the Jurisdiction of the Court, and Scottish Independence: Keatings v Advocate General
}

\section{A. INTRODUCTION}

In Keatings $v$ Advocate General, ${ }^{1}$ the pursuer sought to appeal the decision of the Lord Ordinary (Lady Carmichael) to dismiss his action of declarator. ${ }^{2}$ The pursuer wanted two declarators to confirm that it was within the competence of the Scottish Parliament to legislate unilaterally for an independence referendum, and that no provision of the Scottish Government's proposed legislation on the matter fell outside of that competence. ${ }^{3}$ The Lord Ordinary had refused to make these declarators on the grounds that they were "hypothetical, academic and premature". ${ }^{4}$

The Inner House, consisting of the Lord President (Lord Carloway), Lord Menzies and Lord Doherty, refused the pursuer's appeal and upheld much of the Lord Ordinary's original decision. In the court's view, the action was indeed "premature, hypothetical and academic". ${ }^{5}$ However, the Inner House also held that the jurisdiction of the court to grant a declarator on the competence of a Bill before Royal Assent was excluded by the Scotland Act 1998, thus overturning part of the Lord Ordinary's decision. Despite refusing the declarators, the Inner House also made a series of brief obiter remarks on the legislative competence of the Scottish Parliament in authorising a referendum on Scottish independence.

It is important to consider the constitutional significance of the Inner House's decision and its implications for public law in Scotland. Firstly, the claim will be made that Keatings confirmed the existence of a new public law action of declarator which is separate and distinct from judicial review. Secondly, it will be argued that the Inner House, in finding that the Scotland Act 1998 excludes the jurisdiction of the court to determine the competence of Bills other than by the section 33 procedure, identified an additional ground on which to dismiss the action in Keatings, but otherwise did not significantly limit the future application of public law declarators. Thirdly, it will be shown that the Inner House's obiter remarks on the ability of the Scottish Parliament to legislate for a second independence referendum will help to frame and clarify the legal question for any subsequent litigation on the matter.

\section{B. DECISION}

\section{(1) Public law action of declarator}

Keatings is an important yet unusual public law case because it was brought by the pursuer as an ordinary action of declarator rather than as a petition for judicial review. Judicial review

\footnotetext{
${ }^{1}$ [2021] CSIH 25 (hereafter "Keatings IH").

${ }^{2}$ Keatings v Advocate General for Scotland and the Lord Advocate [2021] CSOH 16 (hereafter "Keatings OH"). See also R.B. Taylor, "Preserving the Rule of Law in Public Law Cases: Keatings v Advocate General for Scotland and the Lord Advocate" (2021) 25 EdinLR 231.

${ }^{3}$ Keatings $\mathrm{OH}$ para 1 ; Keatings $\mathrm{IH}$ para 1.

${ }^{4}$ Keatings $\mathrm{OH}$ para 139.

${ }^{5}$ Keatings IH para 55.
} 
This article has been accepted for publication in the Edinburgh Law Review and is forthcoming in issue (2021) 25:3, pp.362-369. For the Edinburgh Law Review, see https://www.euppublishing.com/loi/ELR.

is the principal mechanism by which public law litigation is brought. However, as per the test in West $v$ Secretary of State for Scotland, ${ }^{6}$ some allegation of unlawful conduct by a public body in the exercise of its delegated authority would normally be required in order for the supervisory jurisdiction of the court to be engaged. No such unlawful conduct was alleged in Keatings. The pursuer instead wanted the courts to confirm the legislative competence of the Scottish Parliament in relation to holding a second independence referendum so as to clarify the choices facing voters in elections on the issue of Scottish independence. ${ }^{7}$ As a result, the pursuer brought an ordinary action of declarator, something traditionally used only in the field of private law.

In doing so the pursuer relied upon the decision of the Inner House in Wightman $v$ Secretary of State for Exiting the European Union, ${ }^{8}$ specifically the comments made by the Lord President (Lord Carloway) therein. ${ }^{9}$ Wightman concerned a petition for judicial review where a declarator on the revocability of Article 50 of the Treaty on European Union ("TEU") was sought. Although no unlawful conduct was alleged in the case, the Inner House nevertheless granted the declarator. In so doing, the Lord President seemed to suggest obiter that the decision could have been brought instead as an ordinary action of declarator. ${ }^{10}$ As I have argued elsewhere, despite dismissing the pursuer's action, the Lord Ordinary in Keatings nevertheless recognised a new standalone public law action of declarator that is separate and distinct from judicial review, thus giving force to the obiter remarks of the Lord President in Wightman. ${ }^{11}$ The Inner House, it is submitted, confirmed this.

In delivering the opinion of the court, the Lord President stated with approval that the case had "proceeded, correctly, as an action rather than a petition for judicial review". ${ }^{12}$ On the question of when the court would decline an application for a declarator, the Lord President reaffirmed his decision in Wightman as follows:

The principle of access to justice requires that, as a generality, anyone can apply to the court to determine what the law is in a given situation. There are limits to this. One of them is that, again as a generality, the court will not determine hypothetical or academic questions. Those are questions, the answers to which have no practical effect. $^{13}$

In so doing, the Inner House, like the Lord Ordinary, did not distinguish between actions of declarator or petitions for judicial review where a declarator is sought (such as Wightman). It

\footnotetext{
${ }^{6} 1992$ SC 385.

${ }^{7}$ Keatings $\mathrm{OH}$ para 45; Keatings IH para 23.

8 [2018] CSIH 62 (hereafter "Wightman IH").

${ }^{9}$ See Keatings $\mathrm{OH}$ para 52; Keatings IH para 23.

${ }^{10}$ Wightman $\mathrm{IH}$ para 26.

11 Taylor (n 2).

12 Keatings IH para 70.

${ }^{13}$ Keatings IH para 51.
} 
This article has been accepted for publication in the Edinburgh Law Review and is forthcoming in issue (2021) 25:3, pp.362-369. For the Edinburgh Law Review, see https://www.euppublishing.com/loi/ELR.

can be reasonably concluded therefore that the requirements for the granting of such a declarator remain the same for both. ${ }^{14}$

Furthermore, the Inner House held that the test for standing in judicial review - the sufficient interest test as stated in AXA General Insurance and others $v$ The Lord Advocate and others ${ }^{15}$ - applied equally to actions of declarator on public law matters as it did to petitions for judicial review, thus confirming the view of the Lord Ordinary. ${ }^{16}$ As the Lord President observed:

Where a bare declarator is sought, it must have a purpose. It must produce a practical result. In so far as this overlaps with title and interest (standing), the result must be one of the person seeking the remedy, although it may also affect others. Whether a person has a sufficient interest depends upon the context ... There is no difference in this area between ordinary actions and petitions for judicial reviews where each seeks a public law remedy. ${ }^{17}$

From the above, it can be clearly seen that the Inner House in Keatings, like the Lord Ordinary before it, recognised the existence of two distinct public law actions: (1) the petition for judicial review; and (2) a new standalone public law action of declarator. Crucially, both share the same rules on standing, the sufficient interest test, with the Inner House also going as far as to suggest that the expenses regime between an action of declarator and a petition for judicial review, in the interest of access to justice, "ought not to be too different". ${ }^{18}$ The recognition of this new public law action, although qualified, nevertheless represents a notable widening of the public law jurisdiction of the court in Scotland. Public law litigation need no longer dependent solely on judicial review and the allegation of unlawful conduct. Keatings is therefore a constitutionally significant decision notwithstanding the fact that the pursuer was ultimately unsuccessful.

Applying the above-mentioned requirements of public law declarators to the facts in Keatings ${ }^{19}$ the Inner House rejected the pursuer's argument that a declarator was required in order for him to exercise his right to vote. ${ }^{20}$ The case before them, the Lord President observed, "is readily distinguishable from Wightman". ${ }^{21}$ In Wightman, MPs had to approve any withdrawal agreement under the terms of the European Union (Withdrawal) Act 2018. Determining the revocability of Article $50 \mathrm{TEU}$, therefore, "clarified the options which were open to MPs in the lead up to what was an inevitable vote on a matter of importance to the UK". ${ }^{22}$ By contrast, Keatings involved only a draft Bill which, unlike a Bill, "has no legal

\footnotetext{
${ }^{14}$ See Taylor (n 2) 236.

15 [2011] UKSC 46.

${ }^{16}$ Keatings $\mathrm{OH}$ para 116 and 124.

${ }^{17}$ Keatings IH para 53.

18 Ibid para 70.

19 Ibid para 53.

${ }^{20} \mathrm{Ibid}$ para 54.

${ }^{21}$ Ibid.

22 Ibid.
} 
This article has been accepted for publication in the Edinburgh Law Review and is forthcoming in issue (2021) 25:3, pp.362-369. For the Edinburgh Law Review, see https://www.euppublishing.com/loi/ELR.

status". ${ }^{23}$ Echoing the view of the Lord Ordinary, ${ }^{24}$ the Inner House emphasised the uncertainty of the situation before them at the time. It was unclear whether or not a Bill authorising an independence referendum would ever be introduced, and if so, to what extent it would change during its passage through Parliament. It was also unclear whether the UK Government would refuse to grant an Order in Council under section 30 of the Scotland Act 1998 ("section 30 Order") empowering the Scottish Parliament to pass such legislation. ${ }^{25}$ If a Bill was ever passed without a section 30 Order, the Lord President further observed that "it is highly probable that the UK Government's law officers would refer the Bill for scrutiny by the UK Supreme Court". ${ }^{26}$ It was accordingly on this basis that the Inner House agreed with the decision of the Lord Ordinary and held that the declarators sought were "premature, hypothetical and academic", and that "[a] decision by this court on the matters litigated would serve no practical purpose". ${ }^{27}$

\section{(2) The Scotland Act 1998 and the jurisdiction of the court}

A key feature of Keatings, and one which distinguished if further from Wightman, was that the pursuer sought declarators on the legislative competence of the Scottish Parliament. However, section 33 of the Scotland Act 1998 already provides a special procedure whereby the UK Supreme Court can determine the competence of Bills referred to it by Scottish and UK law officers before Royal Assent is received.

The defenders in Keatings, the Advocate General for Scotland and the Lord Advocate, had argued throughout that section 33 was the only mechanism by which the competence of proposed legislation could be judicially determined before receiving Royal Assent; the jurisdiction of the court was otherwise excluded by the Scotland Act 1998, including the granting of declarators. ${ }^{28}$ However, the Lord Ordinary, relying principally on the decision of the UK Supreme Court in $A X A$, rejected this outright. ${ }^{29}$

In AXA, the UK Supreme Court held that judicial review of Acts of the Scottish Parliament was not limited only to the terms of section 29 of the Scotland Act 1998, but also included common law grounds with the exception of irrationality. ${ }^{30}$ As Lord Reed famously remarked:

[T] he Scottish Parliament is not a sovereign parliament in the sense that Westminster can be described as sovereign: its powers were conferred by an Act of Parliament, and those powers, being defined, are limited. It is the function of the courts to interpret and apply those limits, and the Scottish Parliament is therefore subject to the jurisdiction of the courts. ${ }^{31}$

\footnotetext{
${ }^{23}$ Ibid para 55.

${ }^{24}$ Keatings $\mathrm{OH}$ paras 103 and 131.

${ }^{25}$ Keatings IH para 55.

26 Ibid.

27 Ibid.

${ }^{28}$ Keatings $\mathrm{OH}$ paras 16-18, 28-29 and 33; Keatings IH paras 30 and 42.

${ }^{29}$ Keatings $\mathrm{OH}$ paras 102-112.

${ }^{30}$ AXA (n 15) paras 45-52 (Lord Hope); paras 135-154 (Lord Reed).

31 Ibid para 138.
} 
This article has been accepted for publication in the Edinburgh Law Review and is forthcoming in issue (2021) 25:3, pp.362-369. For the Edinburgh Law Review, see https://www.euppublishing.com/loi/ELR.

Applying AXA by analogy, the Lord Ordinary therefore concluded that section 33 likewise did not exclude the jurisdiction of the court. ${ }^{32}$ Furthermore, although section 40 of the Scotland Act 1998 excluded the jurisdiction of the court in specific ways with regards to proceedings against the Scottish Parliament, it nevertheless expressly preserved the power of the court to make declarators. ${ }^{33}$ The Scottish Parliament, therefore, "is a creation of statute and remains subject to the jurisdiction of the court where that is not the subject of specific exclusion". ${ }^{34}$ However, irrespective of this wide jurisdiction, the Lord Ordinary was keen to stress that judicial pronouncement on the competence of a Bill would be a rare occurrence. As she noted:

[1]t will generally ... be premature and pointless for the court to adjudicate as to the lawfulness of a proposed act of Parliament at any point before it is passed, because it is open to change by way of amendment at the hands of the Parliament itself until it has been passed. ${ }^{35}$

Furthermore, other remedies existed once legislation was passed, such as before Royal Assent under the above-mentioned section 33 procedure or afterwards via judicial review, thus negating the need for a declarator beforehand. ${ }^{36}$

Therefore, although the courts could make public law declarators on the competence of Bills notwithstanding the section 33 procedure, the Lord Ordinary was of the view that courts will generally not be able to do so due to Bills being subject to change during their passage through Parliament. In other words, the courts are very likely to refuse a declarator in relation to a Bill on the grounds that it is hypothetical, academic and premature.

Whilst the Inner House acknowledged that the Scottish Parliament was subject to the jurisdiction of the court, $^{37}$ it nevertheless disagreed with the Lord Ordinary that this jurisdiction could only be excluded specifically by legislation and thus overturned her decision on this point. ${ }^{38}$ As the Lord President noted, "[e]xclusion can also occur by necessary implication and, in that respect, it is a question of the construction of the particular statute in each situation". ${ }^{39}$ The only occasions where "clear and unambiguous terms" is required in order for the jurisdiction of the court to be excluded is in relation to ouster clauses (statutory provisions which seek to exclude judicial review) and the interference with fundamental human rights. ${ }^{40}$

Keatings, in contrast, involved a specific statutory remedy in the form of section 33. As the Lord President accordingly observed, "[w] here such a specific statutory remedy is inconsistent with the use of an ordinary one, the latter may be held excluded by necessary implication.

\footnotetext{
${ }^{32}$ Keatings $\mathrm{OH}$ paras $109-112$.

33 Ibid para 105.

34 Ibid.

35 Ibid para 131. See also para 103.

36 Ibid para 130.

${ }^{37}$ Keatings IH para 57.

38 Ibid para 58.

39 Ibid.

${ }^{40}$ Ibid para 59.
} 
This article has been accepted for publication in the Edinburgh Law Review and is forthcoming in issue (2021) 25:3, pp.362-369. For the Edinburgh Law Review, see https://www.euppublishing.com/loi/ELR.

That is the situation here". ${ }^{41}$ In the opinion of the Inner House, therefore, the 1998 Act by necessary implication excluded the jurisdiction of the court to grant a declarator on the competence of a Bill before Royal Assent. As the Lord President observed:

The Act goes on to provide expressly for the scrutiny of Bills at a stage after a Bill has been passed by the Parliament but prior to it receiving Royal Assent. It has confined that scrutiny to the Supreme Court of the United Kingdom and then only on the application, within a limited window of time, of the principal law officers of Scotland and the United Kingdom (1998 Act, s 33(1)). This is the only method of scrutinising a measure for legislative competency prior to Royal Assent. ${ }^{42}$

In other words, the Inner House held that the jurisdiction of the court to determine the competence of Bills before Royal Assent is excluded by the Scotland Act 1998 other than by the section 33 procedure. It is submitted that the significance of this decision is threefold. Firstly, in finding this statutory exclusion, the Inner House also identified an additional ground for dismissing the action in Keatings which is necessarily preliminary to the requirements of a public law declarator discussed above. Secondly, although this statutory exclusion does limit the application of public law declarators, it does so only narrowly in relation to the competence of proposed legislation before Royal Assent; public law declarators otherwise remain available where the requirements of the action are satisfied. Consequently, public law declarators still have the potential to play a major role in shaping the future of Scottish public law. Thirdly, the Inner House's recognition of this statutory exclusion made it unequivocally clear that the competence of any Bill authorising a referendum on Scottish independence can only be determined before Royal Assent via the section 33 procedure.

\section{(3) Scottish independence and the competence of the Scottish Parliament}

The pursuer made a wide range of constitutional arguments in support of declarators being made to confirm the ability of the Scottish Parliament to legislate unilaterally for an independence referendum. ${ }^{43}$ Despite refusing the pursuer's appeal on the grounds discussed above, the Inner House nevertheless commented briefly on the merits of the pursuer's arguments. Although strictly obiter, it is submitted that the Lord President's remarks are nevertheless important.

The Inner House confirmed that, had they decided to answer the questions posed by the pursuer, "it would have done so as a matter of straightforward statutory interpretation" ${ }^{44}$ As a result, the court was of the view that the pursuer's arguments regarding the distinctiveness of the Scottish constitutional tradition relative to that of England's "would have been of peripheral relevance in the exercise". ${ }^{45}$ There would therefore be no need to explore the continuing relevance of A.V. Dicey's understanding of parliamentary sovereignty, noting also

\footnotetext{
${ }^{41}$ Ibid.

42 Ibid para 60. See also para 61.

43 Ibid paras 21-22. See also Keatings $\mathrm{OH}$ paras 58-76.

44 Ibid para 63.

45 Ibid para 64. See also para 65.
} 
This article has been accepted for publication in the Edinburgh Law Review and is forthcoming in issue (2021) 25:3, pp.362-369. For the Edinburgh Law Review, see https://www.euppublishing.com/loi/ELR.

that "the pursuer's reports of its demise seem greatly exaggerated" ${ }^{46}$ Instead, the relevant legal question to be decided would be as follows:

[W] hether an Act to hold a referendum on Scottish Independence "relates to" (s.29(2)(b)) "the Union of the Kingdoms of Scotland and England" or "the Parliament of the United Kingdom" (sch 5 part 1 para 1(b) and (c)) having regard to its effect in all circumstances (s.29(3)). The Act would relate to these reserved matters if it had "more than a loose or consequential connection with them" (UK Withdrawal from the EU (Legal Continuity) (Scotland) Bill 2019 SC (UKSC) at para [27], quoting Martin v Most 2020 SC (UKSC) 40, Lord Walker at para [49]). ${ }^{47}$

The Lord President concluded by saying that "[v]iewed in this way, it may not be too difficult to arrive at a conclusion, but that is a matter, perhaps, for another day". ${ }^{48}$

Regardless of the level of difficulty, there is little doubt that different conclusions to the question posed by the Inner House will be reached. Although it is clear that that Scottish independence itself would fall outside of the legislative competence of the Scottish Parliament, it is less clear if the same is true of a referendum on Scottish independence. However, what is clear is that the answer to this question will turn only on the nature of the connection between a referendum on Scottish independence and the Union between England and Scotland or the Westminster Parliament; anything else is irrelevant. These obiter remarks are therefore very significant in framing and clarifying the relevant legal question to be answered, and thus will help to set the stage for the matter to be decided in any future litigation - should the need ever arise.

\section{CONCLUSION}

Although the pursuer was ultimately unsuccessful in seeking an answer to the constitutional questions he posed, Keatings is nevertheless a landmark decision in the development of public law in Scotland. It clarified the law following Wightman in recognising a new standalone public law action of declarator that exists alongside judicial review. Although the Inner House held that the Scotland Act 1998 excluded public law declarators on the competence of Bills before Royal Assent altogether, this does not significantly limit the use of such declarators moving forward. In so doing, the court also made it clear that, should a Bill ever be passed authorising a second independence referendum, questions as to its competence before Royal Assent can only be determined through the section 33 procedure. Furthermore, should this procedure ever be invoked, the court's obiter remarks will no doubt prove useful to the UK Supreme Court in making its decision. Whether this will ever happen, however, remains to be seen.

Robert Brett Taylor University of Aberdeen

\footnotetext{
${ }^{46}$ Ibid para 64.

${ }^{47}$ Ibid para 66.

${ }^{48}$ Ibid.
} 